\title{
The Goal-level Analysis of Shareable Development Concept
}

\section{Mo Chen}

\author{
School on Marxism, Jilin Agricultural University, 2888, Xincheng Street, Changchun, China
}

\author{
Keywords: Shareable Development; Life Equality; Free and Comprehensive Development of \\ Mankind.
}

\begin{abstract}
Xi Jinping, the General Secretary of China, has put forward the five concepts: innovation, coordination, green, open and sharing. Shareable development is one of the five concepts. Deeply understand the meaning and essential of shareable development and grasp its goal level cannot only insight into the direction of people's livelihood development in China, but also grasp its rule, and then improve the livelihood of people in China.
\end{abstract}

\section{Introduction}

Shareable development has been a realistic and necessary link of the development of socialism with Chinese characteristics. Based on such a development concept of people's livelihood, the development of people themselves and the joint development between people and society have become the new demand and target of people's livelihood development. Specifically, the people's livelihood development of our country is to achieve the equality of life, the free and comprehensive development of mankind and the progress of the whole society. Life equality, which has always been the goal the people pursue to, is the basic target of the shareable development concept. To give people their deserved appropriately by Plato, the philosopher of ancient Greece, everyone is equal before Jesus in medieval Europe and equality before the law in modern western bourgeois have shouted out people's anticipation and their waiting for. But these shouts are hard to realize. In the states which are based on private ownership, in order to maintain their dominant position, the ruling class will definitely strengthen the exploitation of ruled classes which leads to the inequality in reality. While these equality ideas have become an anger catharsis of people to the reality. Marx stands at the height of all mankind to criticize that the capitalist system is the source of inequality, and to point out the equality is peoples' consciousness of their own in practice field, that is, people realize the others are as equal as themselves and treat them as the equal person as themselves [1].

\section{Shareable development}

Any true philosophy is all the spiritual essence of its times. [2]. Shareable development is the Marxism philosophical thinking of our party about the current Chinese society, the primary meaning is to realize life equality which means the equality of all beings include people and other creatures. On the one hand, we want to ensure that more than 1.3 billion people could share the common development opportunities, and the social development achievements could meet everyone's needs of basic survival, requirement, development and self-value realization. On the other hand, we need a long-term awareness, our development is not only to meet the needs of human beings, but also to follow the nature's development law. Survival and development with other creatures, as Marx said, man is a duality of existence: subjectively exists as himself, objectively exists in these natural inorganic conditions which he lives in. [3]

The free and comprehensive development of mankind is the vertical target of shareable concept. From the perspective of historical materialism, resurrection of humanity and comprehensive development of mankind are the nature need of human beings. Marx pointed out, the global property of a species and its genus nature lie in the quality of life, and genus nature of man is activating freely and consciously. [4] Human essence is not an inherent abstraction for a single person, on reality, it is the sum of all the social relations. [5] Marx created scientific socialism while criticized the capitalist 
society profoundly, and further pointed out that the communist society in the future would be a more advanced social formation, with each person's free and comprehensive development as the basic principle.

People's free and comprehensive development is the time responsibility of Chinese Communist Party. As Hegel said, the purpose of society and country is to allow all potentials of human beings and all personal abilities to develop in all aspects and all directions. [6] Since Marxism widespread in China, the Chinese people had accepted the concept of people's free and comprehensive development. Chinese advanced intellectuals organize Chinese Communist Party in the direction of Marxism, since then, to set up a society in which the people are the masters has become the historical mission of the Chinese Communist Party. The Chinese Communist Party combines the personal free and comprehensive development and national independence and emancipation. Mao Zedong put forward that, the Chinese Communist Party asks for independence on behalf of the national people. China has no personality without independence, national liberation is the liberation of personality, we should do this politically, economically, and culturally also. The masses could not be respected without distinct, awakening, democratic and independent consciousness. [7] Based on the consensus of personal free and comprehensive development and national independence and emancipation, the Chinese Communist Party selects revolutionary struggle as implementation model, over half a century after new-democratic revolution and socialist revolution, the socialist system has been established. In order to further realize the free and comprehensive development of people, on the road of socialist construction, Deng Xiaoping, Jiang Zemin and Hu Jintao and other leaders take specific quantified targets to further promote the concept of people's comprehensive development based on Chinese characteristics. Common prosperity thoughts, well-off society and scientific development and other theories are the most realistic and accurate grasp of the comprehensive development of the society in China. From the present social existence and material condition of our country, Xi Jinping grasps the pulse of the times, conforms to people's livelihood and well-being, puts forward four comprehensive theories and Chinese dream in comprehensive, developmental and universal view, and points out definitely that, to achieve common prosperity for the whole country gradually and people's free overall development. [8] The Chinese dream is a national dream, and also a dream of every Chinese. [9] Not only summarized the development view based on human beings on the road of socialist with Chinese characteristics in theory, but also pointed out the essence of people's livelihood development in representational aspect, namely free and comprehensive development of mankind. This is further enrichment and development of the socialist essence.

Social overall progress is the horizontal target of shareable development concept. Society is an organic whole, is the realized essential unity between humans and nature. [10] At the same time, Marx points out that, society is not made up by individuals, it manifests the sum of all the connections and relations which individuals have. [11] The sum of connections and relations shows natural relation as well as social relations, and these relations constitutes the whole of human society. Only economy, politics, culture and society developed harmoniously, productivity met productive relation, and superstructure met economic base, society could develop really. Since the eighteenth congress, the four comprehensive strategic layout is further emancipation and adjustment of current productive relation and social relation in our country, it points out the necessity of the overall development of the society profoundly. We lay emphasis on be bold and courageous, and take steady steps. Take steady steps is to consider overall, argument comprehensively and decide scientifically. Economic, political, cultural, social and ecological civilization reforms are closely associated with Party construction reform. Reform in any field could affect other fields, and needs the accommodation by other fields' reform at the same time. [12] The proposition of five concepts: innovation, coordination, green, open and sharing has enrich the overall development thought of Party further, is a new paradigm of integration between Marxist progressive though of the whole society and China's actual condition. 


\section{Conclusion}

The real contents of all epoch making systems are formed by the needs that produced these systems during that period." [13] Shared development as a new strategic goal of livelihood development in our country, it reflects targeted results of the productivity development level and the people's livelihood development in our country. Clearing target dimension of shared development concept can grasp the connotation and essence of people's livelihood development in our country, and then better promote the reform and opening up of our country, realize the dialectical unity of scientific socialism logic and the historical logic of socialism with Chinese characteristics

\section{References}

[1]. Marx, Engels, The Holy Family, The Complete Works of Marx and Engels, vol 2 [M]. Beijing: People's Publishing House, 2017 (48)

[2]. The Complete Works of Marx and Engels, vol 1. People's Publishing House, 1956 (121) (60)

[3]. Marx, Economics Manuscripts 1857-1858, The Complete Works of Marx and Engels, vol 30. Beijing: People's Publishing House, 1995 (484)

[4]. Marx, Economic and Philosophical Manuscripts 1844, People's Publishing House, 2000 (57)

[5]. Hegel, Aesthetics, vol 1, Zhu Guangqian translate. The commercial press, 1979 (59)

[6]. The reports and speeches of Mao Zedong at the 7th CPC National Congress, vol 6. The central literature press, 1995 (141)

[7]. [21] Xi Jinping in governing, [M]. Beijing: Foreign languages press, 2014 (9) (40)

[8]. The Complete Works of Marx and Engels, vol 42. [M]. Beijing: People's Publishing House, 1979 (122)

[9]. The Complete Works of Marx and Engels, vol 46. [M]. Beijing: People's Publishing House, 1979 (220)

[10]. Xi Jinping, Explanation on the decision of CPC Central Committee about a number of major issues on comprehensive and deepen reform. People's Daily, 2014

[11]. Xi Jinping, Explanation on the decision of CPC Central Committee about a number of major issues on comprehensive and deepen reform. People's Daily, 2014 